\title{
English Law, Brahmo Marriage, and the Problem of Religious Difference: Civil Marriage Laws in Britain and India
}

\author{
NANDINI CHATTERJEE
}

\section{University of Plymouth}

THE “CIVIL” OF CIVIL MARRIAGE

On the face of it, civil marriage represents both the most typical and most anodyne aspect of modern law. One might say that by instituting civil marriage, a bureaucratic, enumerative, and secularized state permits its subjects absolute individual choice of marital partners, and concurrently, by refusing to take into account the religious affiliation of any party, grants total freedom of religious faith. As such, it may be seen as a quintessentially modern phenomenon, connected through the adjective "civil" with other distinctively modern concepts such as civil society, all of which point to a notion of individual liberty, predicated upon a modern state guaranteeing the autonomy of large arenas of social life.

Indeed, the few existing studies of European civil marriage laws do take such a view. One scholar asserted upfront, "If the central characteristic of democratic capitalist society is mass choice, then democratic capitalist marriage arrived in Britain on 1 July 1837" (the date on which the Marriage Act of 1836, which for the first time permitted civil marriage, came into operation). ${ }^{1}$ Prior to this, all marriages to be legally valid had to be celebrated in an Anglican church, in daylight hours, with appropriate Anglican ceremonies conducted by an officiating Anglican priest. Excepted were the marriages of Jews and Quakers, royal marriages, marriages abroad, and marriages under the Archbishop's special

\footnotetext{
Acknowledgments: The earliest version of this article was presented at the annual conference of the Law and Society Association, in Berlin, July 2007. I am grateful to Tanika Sarkar for alerting me to the importance of Rabindranath Tagore's Gora as a key source for this article. I also thank the three anonymous CSSH referees for their meticulous and encouraging feedback, and David Akin for his fine editorial chiseling of this article.

${ }^{1}$ Olive Anderson, "The Incidence of Civil Marriage in Victorian England and Wales," Past and Present 69 (Nov. 1965): 50-87, at 50.
} 
license. ${ }^{2}$ The freedom that the new law offered was therefore from the authority of an established church. Unsurprisingly, the demand for this was officially voiced by those who did not belong to the established church, in particular the Nonconformists. How the law was used turned out to be regionally variable, and although scholars have been divided over the reasons for such variation, the consensus appears to be that the ideology of secularism had little to do with it. ${ }^{3}$

The passing reference to secularism in the debate over British civil marriage laws indicates the larger theoretical significance of a set of administrative laws relating to "personal matters," which ostensibly have little to do with the political system. But it is precisely in the "personal" realm, and during near universal life-cycle events such as birth, marriage, and death, that the majority of people most frequently confront both organized religion and the legal consequences of religious confession. In fact, the very distinction between a "personal" sphere where "private" beliefs (including religious beliefs) may be safely held without their effects spilling into the "public" world of the market and the polity is characteristic of modernizing ideologies, even if this is unevenly achieved in practice. A history of marriage laws, especially of those explicitly associated with the problem of religious difference, can therefore serve as an entry into the debates about "secularization," or theories of distinctively modern religion-state relationships.

Secularism is of course a suspect and amorphous term, and nowhere more so than in South Asian studies. A compendium of scholarly usages of the term would reveal an almost infinite number of distinct definitions ranging from secularism-as-ideology to secularism-as-theory-of-social change, usually with unselfconscious combinations of the subjective and the objective. It is not even clear whether these may be legitimately uncoupled; José Casanova attempted to produce a summary of the "pure" sociological theory by parsing it into its three components: that with modernity, religion (a) declines, (b) is privatized, and (c) is institutionally differentiated from other spheres of social life. ${ }^{4}$ Casanova's own argument, based on his studies of political and highly public religions in Europe and the Americas, is that only the third part of this theory is at present credible. If we followed his model, it would be possible to say that the British civil marriage law of 1836 was symptomatic

${ }^{2}$ H.S.Q. Henriques, "Jewish Marriages and the English law," Jewish Quarterly Review 20, 3 (1908): 391-449, at 400. Also see below.

3 Roderick Floude and Pat Thane, "Debate: The Incidence of Civil Marriage in Victorian England and Wales," Past and Present 84 (Aug. 1979): 146-54; Olive Anderson, "The Incidence of Civil Marriage in Victorian England and Wales: A Rejoinder," Past and Present 84 (Aug. 1979): $155-62$.

4 José Casanova, "Rethinking Secularization," Hedgehog Review 8, 1-2 (2006): 7-22, at 7. Here Casanova summarizes his larger and massively influential work, Public Religions in the Modern World (Chicago, 1997). 
of the secularization process, even if none of the parties that debated it articulated an explicit ideology of secularism.

Most South Asianists would question the legitimacy of such a distinction. As Talal Asad has observed, institutional differentiation may not be a meaningful concept when religious ideology can clearly inform economic, pedagogic, and political behavior. Asad himself looks at secularism (or the secular) as a normative idea, actively pursued by modern or would-be-modern states, which assumes a priori that there exists a differentiable quantity, called religion, which can influence society without being merged in it. ${ }^{5}$ Postcolonial criticism has also complicated the relation between secularism, modernity, and liberty. If the secular state does not simply liberate the citizen from the clutches of religion, what does it then do? Asad has suggested that it demands of citizens transcendent loyalty to the nation-state, in an apparently paradoxical extension of the principle of cuius regio eius religio (the religion of the ruler is the religion of the subjects). In the process of demanding the prioritization of loyalties, it also authoritatively constructs the entity that it ostensibly wishes to distance itself and its subjects' primary loyalties from: the thing called "religion."6

In tune with this theoretical trend, this article proceeds from the premise that the modern state is a more demanding state, that the nature of liberty such a state affords is not permissive in absolute terms, but only in relation to other authorities that compete with its own claims over its subjects. But I also think, perhaps somewhat differently from Asad, that greater attention needs to be paid to the manner in which the modern state claims authority to regulate, rather than marginalize, religious affiliation. In 1894-1895, for example, Hungary (to cite one of the few studies of civil marriage laws anywhere in the world) legislated compulsory civil marriage, with the children of "mixed marriages" (i.e., born of parents belonging to different churches) required to register as belonging to the confession of the parent of their same sex. By compelling the registration of both marriages and births, and by making the state's authority transcendent in determining individual religious identity, the Hungarian nation-state explicitly demolished the competing claims of its most formidable rival, the Catholic Church. ${ }^{7}$ I see clear similarities between the Hungarian

5 Talal Asad, Formations of the Secular: Christianity, Islam, Modernity (Stanford, 2003), 181201. Asad has also pointed out that "institutional differentiation" means radically different policies in countries such as the United States and France. In "Responses," in David Scott and Charles Hirschkind, eds., Powers of the Secular Modern: Talal Asad and His Interlocutors (Stanford, 2006), 207-10.

6 Talal Asad, "French Secularism and the "Islamic Veil Affair," Hedgehog Review 8, 1-2 (2006): 93-106, at 4. In my reading, a similar argument is made by Veena Das with respect to the British imperial state in India, in her "Secularism and the Argument from Nature," in Scott and Hirschkind, eds., Powers of the Secular Modern, 93-112.

7 Robert Nemes, "The Uncivil Origins of Civil Marriage: Hungary," in Christopher Clark and Wolfram Kaiser, eds., Culture Wars: Secular-Catholic Conflict in Nineteenth-Century Europe (Cambridge, 2003), 313-35. 
law and those in Britain and India; all were passed in the same century and each was an instance of the modern state (nation-state or imperial state) successfully claiming supreme authority over the regulation of religious affiliation. State secularism does not imply the withdrawal of the state from religious matters, but on the contrary it consists of the state assuming the role of the ultimate regulator of religious affiliations and arbiter of religious claims. ${ }^{8}$

What, then, about state secularism in British-ruled colonial India? A large number of postcolonial scholars have asserted that India is a society where religions are total ways of life that cannot be validly differentiated to yield a pure secular sphere of social life, ethics, and politics. ${ }^{9}$ From this perspective, state secularism in colonial India was purely the effect of the modernizing will of an arbitrary and alien state, a will that "westernized" Indian ruling elites have continued to adopt under the postcolonial dispensations. If this is so, then one could explain the appearance of a civil marriage law in India in 1872 as an unremarkable symptom of the general Britain-led modernization program there.

Apart from serious doubts regarding Britain's commitment to modernizing colonial India, ${ }^{10}$ there is a relatively recent suspicion that this chronology itself is incorrect, that Britain may not have been "modern" in time to "modernize" India (however inadequately). If, on the other hand, "modernity," both

8 There is an argument that by the nineteenth century, religious difference ceased to matter, or matter much, for European states, which became increasingly preoccupied with racial distinctions instead. See Peter van der Veer, Imperial Encounters: Religion and Modernity in India and Britain (Princeton, 2001), 22. But religion and race are not quite the mutually exclusive ontological categories that they are often taken to be. Not only is there is a clear genealogical connection between these two taxonomic systems, but there have been constant exchanges between them, especially in the context of European and European-imperial law from the eighteenth century until today. I have argued this in connection with a case in Calcutta in 1756; see Nandini Chatterjee, "Religious Change, Social Conflict and Legal Competition: The Emergence of Christian Personal Law in Colonial India," Modern Asian Studies (doi:10.1017/S0026749X09990394 published online by Cambridge University Press, 21 April 2010). In my understanding, Nazi Germany's antimiscegenation laws were the direct descendents of nineteenth-century Prussian laws aimed at discouraging "inappropriate" religious choices, that is, conversion to Judaism. Christopher Clark, "The Limits of the Confessional State: Conversions to Judaism in Prussia 1814-1843," Past and Present 147 (May 1995): 159-79. One can detect the same conceptual contortions in the House of Lords' discovery (in Mandla [Seva Singh] and another v. Dowell Lee and others [1983], 2 AC 548) that Sikhs were a "race" rather than a "religion," as they had been deemed until then, a discovery that enabled them to extend protection under the Race Relations Act 1976 to Gurinder Singh Mandla, excluded from a private school for insisting on wearing his turban.

9 T. N. Madan, "Whither Indian Secularism?" Modern Asian Studies 27, 3 (1993): 667-97; Ashish Nandy, "The Politics of Secularism and the Recovery of Religious Tolerance," in Rajeev Bhargava, ed., Secularism and Its Critics (New Delhi, 1998), 321-44.

10 David Washbrook has most strongly proposed that British rule "traditionalized" India rather than the other way round. In "India, 1818-1860: The Two Faces of Colonialism," in Andrew Porter, ed., Oxford History of the British Empire, vol. 3 (Oxford, 1999), 395-421. Most scholars subscribe to the view that British enthusiasm for reform and modernization wore off after the debacle of the Mutiny of 1857 , and with the rising conviction in the incorrigibility of inferior races in Victorian Britain. 
Britain's and India's, was the product of the interaction itself, ${ }^{11}$ then one needs to accord greater causative weight to the interactive process. This is what this article does, at the micro-level of laws dealing with marriage and religious status.

I will argue that the civil marriage laws of Britain and India were products of a distinctively modern legal approach towards religious toleration, which arbitrated between rather than ignored religious difference, and in the process of doing so engendered a novel species of political competition in colonial India. This competition consisted of collective claims asserted to be religious and accepted as such by the state. A host of scholars have commented on the unprecedented hardening of religious and other ascriptive social boundaries in India under colonial rule, and here we can trace the actual process of redirection of competition from other social fora toward the state, and the resultant re-articulation of social identities in law as well as the public sphere. A crucial, but by no means omnipotent role was played in this process by the colonial state, which through the very fact of declaring a policy of religious "neutrality" committed itself to the identification of religious "rights" borne by entities known as religious communities. The situation was in many ways unprecedented, but it also possessed sufficient commonalities with recent religious and legal developments in Britain for British legislators in India to adopt models derived from Britain to resolve the competing claims in India. By tracing how the process produced two formally similar but substantively different civil marriage laws, in Britain and India, I will showcase the process of lawmaking in colonial India, and add to the historiography of the modern state and its relation to religion.

I will also speak, though less directly, to how ties of kinship, affection, and authority were restructured, a process that in the nineteenth century produced the modern bourgeois family in Britain, and to a limited extent in India as well. I will suggest some reasons why that model of interpersonal relationships found only limited and delayed success in India. In doing so, I will highlight differences in legal structure and political competition rather than cultural specificities such as an innate Indian tendency towards unwieldy extended families and arranged marriages.

11 This has been argued for some time now, for example in Gauri Viswanathan, Masks of Conquest: Literary Studies and British Rule in India (London, 1990); Peter van der Veer, Imperial Encounters; and more recently by Jon Wilson in The Domination of Strangers: Modern Governance in Eastern India, 1780-1835 (Basingstoke, 2008). These scholars however define this co-emergent "modernity" in different ways. While van der Veer and Viswanathan point toward its "known" aspects, such as secularism, Wilson reverts to classical social theory in defining it as abstraction, of law, policy, and even people's self-perceptions, from the lived reality of social life. Also, Wilson's modernity is much more universal, affecting Indians and Britons alike, whereas Viswanathan and van der Veer have both argued for the continued existence of social and intellectual formations outside of modernity. 


\section{COLONIAL CIVILITY: AN ALIEN IMPOSITION?}

Recently a minor piece of colonial Indian legislation known the Special Marriage Act, legislated in 1872 as Act III of that year, has emerged from obscurity due to the attentions of scholars interested in the triangle of law, religion and marriage. ${ }^{12}$ Officially titled "An Act to Provide a Form of Marriage in Certain Cases," the Special Marriage Act has come to be seen as India's first civil marriage law, ${ }^{13}$ and, with several amendments, it is the current law as well. Scholars have noted certain irregularities in the history of this law of the sort that historians delight in explaining. It was a law that was condemned by its opponents as revolutionary, but which also failed to satisfy its proponents, to the extent that its principal advocate, an eccentric and charismatic Indian religious leader called Keshub Chandra Sen, was himself party to its violation within seven years of its passing. Why, then, was this law enacted at all?

In the most immediate terms, the process of legislation commenced with Keshub Chandra Sen making a petition in 1868 to the Government of India on behalf of the Brahmo Samaj for a law that would secure the legality of Brahmo marriages. ${ }^{14}$ The Samaj was an association, principally of upper caste Bengali Hindus, committed to the "reform" of religious doctrine, forms of worship, and social mores, one among various such socio-religious reform efforts that proliferated in nineteenth-century India. ${ }^{15}$ It was established in 1828 by Raja Rammohan Roy, "the father of modern India" in nationalist hagiography. A near outcast to many of his contemporaries, he has been recently reappraised as one of the earliest constitutional liberals of India. ${ }^{16}$ From the start, the Brahmo Samaj's members demonstrated ambivalence about the social implications of religious reform that affected all religious reform movements in India, from long before the colonial period. Over time, the Samaj adopted a sanitized (non-idolatrous) worship and marriage ritual, and from the 1860s it was associated with a miniscule number of unorthodox marriages between men and women of different castes, and in some cases, involving widowed women. It was in this context that Keshub, the leader of

12 I am principally referring to Perveez Mody's "Love and the Law: Love-Marriage in Delhi," Modern Asian Studies 36: 1 (2002): 223-56; re-stated in, "A Form of Marriage in Certain Cases," in her The Intimate State: Love-Marriage and the Law in Delhi (London, 2008), 61-102; and Rochona Majumdar, Marriage and Modernity: Family Values in Colonial Bengal (Durham and London, 2009), 167-205. I will refer to earlier discussions of the law, presently.

13 Erroneously so, since the first law to permit civil marriage in India was passed in 1851 , but was limited to marriages where at least one partner was Christian. I will discuss that law, below.

14 Minute by Henry Maine on the Bill to legalize marriages between certain Natives of India not professing the Christian religion, Government of India Legislative Proceedings 1868, 19 Sept., nos. 15-16, 277-82, P/436/55, Asia Pacific and Africa Collections, British Library.

15 Kenneth W. Jones, Socio-Religious Reform Movements in British India, New Cambridge History of India, III, 1 (Cambridge, 1989).

${ }^{16}$ C. A. Bayly, "Rammohan Roy and the Advent of Constitutional Liberalism in India, 180030," Modern Intellectual History 4, 1 (2007): 25-41. 
the Brahmo Samaj, questioned the Advocate General of India regarding the validity of such marriages, and being informed of their fragile legal status, petitioned for an appropriate law.

Mody's study of the history of the Special Marriage Act takes the view that Keshub's petition was an appeal for recognition of Brahmos as a "distinct 'community,' with legitimate rites of marriage," an appeal whose specifics, and ultimately whose essence was ignored by British legislators. According to Mody, the latter were keen to create a "civil marriage law for all Indians, so that those choosing to dissent from the religious practices of their marriage rites could find state sanction for their acts even if they were disowned by their families, caste or ethno-religious communities." 17 Even with the quotation marks, the idea that Brahmos were a definite and bounded collective, a religious community, appealing for its rights to a secular and insensitive colonial government, informs the chapter of legal history in Mody's otherwise rich and nuanced study of north Indian "love-marriages" (She uses this Indian-English colloquial term to define marriages based on individual choice rather than "social choice," as represented by the wishes of the families.) Through an impressive legal ethnography conducted over several years in the Indian capital of Delhi, Mody examines the implication of the contemporary (officially modern and secular) Indian nation-state in the enforcement of socio-religious orthodoxy, and the dominant ("metropolitan") view of legitimate marriage. As she convincingly demonstrates, the state is implicated by its failure to protect the individual liberty it proclaims, such that vigilantism flourishes with impunity, and also by the deterrence exercised by the working of an administrative and legal system in which lower-level functionaries are personally biased against "love-marriage." 18 In the broader context of Mody's monograph, the purpose of the chapter on legal history is to establish a historical genealogy for the divergence between dominant Indian social norms and formal legal principles, a divergence that remains rife with potential for repression of individuality but also for its rebellious expression. ${ }^{19}$

Mody suggests that the reason that the government, and particularly the law member Henry Maine, took the expansive route to marriage legislation was Maine's evolutionary vision of society proceeding from status to contract, such that "marriages arranged by caste and kinship would give way to marriages based on individual contract." His vision, according to Mody, encompassed a view that religious affiliation should be a matter of individual choice, an idea that she believes to be symptomatic of secularization and loss of faith among intellectuals within Europe. ${ }^{20}$ This is a somewhat inaccurate

${ }^{17}$ Mody, "Love and the Law," 223.

18 Ibid., 223-56 (re-stated in Mody, "A Form of Marriage," 61-102).

19 Ibid., 62-64.

${ }^{20}$ Ibid., 228, 230. Mody repeats the view that the primary reason for this legislation was to be found in a British modernization program for India, in The Intimate State, 80. 
treatment of Maine's ideas and its effects on imperial policy. ${ }^{21}$ Mody also relies excessively on Louis Dumont to explain Indian abhorrence for notions of individual sexual-emotional and religious autonomy that are apparently inseparable from civil marriage. ${ }^{22}$

In line with the rest of her argument, Mody describes Indians, or rather Indian religious "communities," as having vociferously resisted such an idea of marriage and personhood, such that the colonial state was forced to add a self-excommunication clause, according to which couples marrying under this law had to declare that they did not profess the "Christian, Jewish, Hindu, Muhammadan, Parsi, Buddhist, Sikh, or Jaina religions." ${ }^{23}$ In case the threat of "excommunication" was not enough, deterrent administrative provisions were added, such as the requirement of an extended residence in the district of marriage (two weeks in 1872, extended to thirty days in 1954). These made it nearly impossible for eloping couples exercising individual choice to use the law, when their families could pursue and effectively deter them. Although in 1954 the amended Act did not include the excommunication clause, due to the promotion of "individual" rights by (presumably westernized) Indian constitution-makers such as Dr. Ambedkar, the law remains barely usable because of universal social disapproval and the barriers created by administrative law. ${ }^{24}$

Mody argues that this law, unloved by most Indians, was essentially the product of "a secularizing impulse in colonial matrimonial legislation," a powerful impulse that remained active among the "avant-garde" leaders of post-colonial India, especially the discordantly paired Jawaharlal Nehru and B. R. Ambedkar. This view is shared by Majumdar, who sweepingly suggests, "[All?] marriage laws in colonial India bore the stamp of this tussle between a secularized notion of law and a ritualized performance of community identity."25

21 In general, Maine's identity as a liberal modernizer has long been discarded. Scholars have pointed out that while he postulated that all progressive societies had "hitherto" moved from status to contract, he thought that this trajectory was historically specific, and certainly did not predict nor recommend that all societies would embark upon the same journey. John W. Burrow, "Henry Maine and Mid-Victorian Ideas of Progress," in Alan Diamond, ed., The Victorian Achievement of Sir Henry Maine (Cambridge, 1991), 55-69. In fact, Maine's thoughts lent themselves to the ideology of imperial conservatism that characterized late Victorian colonial governance in India. See Clive Dewey, "The Influence of Sir Henry Maine on Agrarian Policy in India," in ibid., 351-75. C. A. Bayly has also suggested that Maine-derived conservatism was particularly successful in India because it resonated with Indian nationalist conservatism at the end of the nineteenth century. C.A. Bayly, "Maine and Change in Nineteenth-Century India," in ibid., 389-97. Also see Karuna Mantena, "The Crisis of Liberal Imperialism," in Duncan Bell, ed., Victorian Visions of the Global Order: Empire and International Relations in Nineteenth-Century Political Thought (Cambridge, 2007), 113-35.

22 Mody, "Love and the Law," 224-27.

23 Act III of 1872 , s. 2 , and Schedule II.

24 Mody, "Love and the Law," 240-41.

25 Majumdar, Marriage and Modernity, 167-70. 
I disagree with the broader argument of these two scholars, who would characterize non-European modernity as an import or imposition, except where modernity takes alternative forms, inevitably marked by exotic ceremonial, and also inevitably performed in the inner or private sphere, which, as Partha Chatterjee famously suggested, was the creative realm of indigenous anti-colonial nationalisms. ${ }^{26}$ The non-western post-colonial state deserves a richer history than that which emerges if it is stereotyped as the cast-off machinery of imperial domination; much that is universal about Indian modernity also derives from a unique province of the historical past, just as is the case with European modernities.

To see Keshub's petition for a separate law of marriage as equivalent to a Brahmo demand for recognition as a distinct collective religious community, and to explain the ultimately abstract and universal form of the law as the product of secular ideologies, pursued first by British colonial statesmen, and subsequently by "avant-garde" postcolonial Indian leaders, one has to commit oneself to two a priori assumptions: first that there was a "modern" British distaste for legally recognizing stable and bounded social groupings, including religious communities, and second, that the Brahmos were in fact such a stable and bounded collective defined by their religion, even if they disagreed occasionally about who belonged. I will argue that neither proposition is defensible.

To begin with the British, I will argue that from the perspective of British legislators the Special Marriage Act was an explicit effort to accommodate $\mathrm{col}$ lective religious difference, rather than an expression of universalistic principles of individual liberty. Further, such an effort was partly derived from the nature of nineteenth-century British marital legislations, which, incidentally, were as much about religious rites and rights of religious communities as about the rights of parties to a marriage. It also derived from the specifically imperial policy of recognizing and administering a system of personal laws, or religion-based "family laws," that had been developing in colonial India since the late eighteenth century.

As for the Brahmos, they provide not just a representative, but a disproportionately important case on which to test theories about the origins of marriage legislations in colonial India, and the nature of Indian religious "communities," defined, or seeking to be defined, by their personal laws - the laws of family life, property, and religion. As Mody and Majumdar both recognize, the Special Marriage Act was tremendously divisive for the Brahmos above all. The proposal for legislation immediately alienated Debendranath Tagore's more conservative Adi Brahmo Samaj from the Keshub-led section, and a further split followed between the "radically progressive" Sadharan Brahmo

\footnotetext{
${ }^{26}$ Partha Chatterjee, The Nation and Its Fragments: Colonial and Postcolonial Histories, $2 \mathrm{~d}$ ed. (New Delhi, 1995), 1-13.
} 
Samaj and Keshub's Nababidhan, or New Dispensation. Were these divisions the result of an unwanted and rigid law being imposed on unsuspecting Brahmos by the British, or were they already extant, but pushed further using ammunition actively sought from the state by particular sections of the so-called Brahmo "community"? In other words, did the community and the state really inhabit different and mutually antagonistic spheres? Let us begin by examining the British side of the story.

A GENERAL EXPLANATION OF CIVIL MARRIAGE? BRITAIN IN THE NINETEENTH CENTURY

Scholars often point to Luther's recommendation that marriage be seen as a civil contract rather than a sacrament as an originary moment for civil marriage $^{27}$ (thus sustaining the larger argument that Protestantism led to secularization). But this presents a problem in that the two or three intervening centuries until civil marriage really became possible in different European countries must be seen as a mere waiting period. Furthermore, it does nothing to explain the differences between the laws of different countries. Consider England in the late eighteenth and early nineteenth centuries: unless one was a Quaker or a Jew, one could only be legally married in Anglican church, by an Anglican priest, with full Anglican rites. This applied equally to Nonconformists, Roman Catholics, and non-Christians. Thus Din Muhammad, a Bengali Muslim ex-sepoy who traveled to Britain in the nineteenth century and set up a vigorous medico-cosmetic business in "shampooing," married an Irish Protestant woman called Jane Daly in 1786 in an Anglican church. His biographer assumes that Muhammad would have by this time become Christian, ${ }^{28}$ a supposition strengthened by his later decision to have his son baptized. But there is no evidence that he had actually changed his religion, and that he married a second time around 1806 would indicate that he certainly did not take all Christian doctrines seriously. But the question for us here is whether he had to be Christian to marry in an Anglican church. ${ }^{29}$ It appears to me that he did not, and in fact there was no other legal method by which Jane could have married him in British-ruled Ireland. This was because Lord Hardwicke's Act of 1753 (26 Geo. II c. 23) outlawed all marriages not duly celebrated, ministered, and registered in an Anglican church or chapel, with five exceptions: the Archbishop's license, royal marriages, marriages abroad

27 Olive Anderson, "The Incidence of Civil Marriage," 77, esp. n. 45.

28 The Travels of Dean Mahomet: An Eighteenth-Century Journey through India, Michael H. Fischer, ed. (Berkeley, 1997), 209.

29 Professor Fisher called my attention to the fact that the couple had to declare themselves members of the congregation. But he also agreed that there were pious Muslims who married Christians in church (personal communication, 15 Apr. 2008). One such person was Mir Hasan Ali, whose English wife later undertook an ethnography of Indian Muslim customs. Mrs. Meer Hasan Ali, Observations on the Mussulmans of India (London, 1832). 
(provided such marriage were celebrated by a law that recognized Christian marriage), marriages between Jews, and between Quakers. ${ }^{30}$ Din Muhammad would not have qualified for any of these exemptions. ${ }^{31}$

Let us examine what was happening here in mid-eighteenth-century Britain. The 1753 law did not separate the church and the state, but rather bolstered the authority of the Anglican Church far beyond the capacity of the church itself. As before, canon law remained the only form of marriage law, and ecclesiastical courts continued to possess near-exclusive jurisdiction over matrimonial disputes. $^{32}$ The Anglican Church continued to function as an arm of the state, levying tithes for the functions of parish governance, including poor relief. With the 1753 law, the connection became even closer, with the church serving the modern state's aims of creating a legible and governable population, but also its own, securing compliance to a degree it had never achieved before. $^{33}$

Did "secularization" happen in England in 1837 then, when the first civil marriage law came into force? This law permitted three possible locations and forms of marriage: an Anglican church by Anglican rites (preceded by banns, license, or the registrar's license), in a registered Nonconformist chapel or Roman Catholic church by appropriate rites in the presence of a registrar, and at the registrar's office without religious ceremonies. Both the latter forms had to be preceded by the issuing of a license or certificate by the registrar. $^{34}$ This tri-fold categorization-which was based on and explicitly referred to the nature of religious rites employed - resists any religious-secular typology: Anglican church marriages could follow both religious and civil preliminaries, the chapel marriage had to be preceded by civil license. This hardly made religion irrelevant to the state; the law offered a limited set of religious choices, which were unequally distributed. As Nonconformists continued to complain, marriage in a chapel remained more difficult, more expensive, and not automatically valid; not until 1898 could the presence of the registrar be dispensed

${ }^{30}$ H.S.Q. Henriques, "Jewish Marriages and the English Law," 400.

31 The irony was that while mixed marriages between Catholics and Protestants were prohibited in Ireland until 1792 under the penal laws, Din Muhammad, might have slipped through the net by belonging to neither category.

32 The provision for a private bill of divorce in Parliament, available since the Tudors, was for obvious reasons not a substantive reality for most people. Other causes, such as enforcing a marriage contract (rather than dissolving it) remained under ecclesiastical jurisdiction. For the working of ecclesiastical courts for matrimonial disputes prior to 1857, before the first civil courts for divorce were created, see R. H. Helmholz, Marriage Litigation in Medieval England (London, 1974).

33 While "informal marriage," which was not only outside the church but often no more than a verbal promise, was valid if made in the present tense, "per verba de presenti," it was difficult to establish in dispute, and hence discouraged by the church. By the sixteenth century, the presence of priest began to be considered crucially important, but even so, verbal contracts remained legally enforceable until 1753. Ibid., 64-65.

346 and 7 Will. IV c. 85 . 
with for churches in Nonconformist and Roman Catholic marriages. ${ }^{35}$ This point can be extended today to the registration of Hindu and Muslim marriages, the difficulties of Nonconformists being almost exactly replicated with regard to the unsure legal status of non-Christian religious functionaries or of buildings that are not registered for performance of marriages. ${ }^{36}$ It appears that in Britain since 1837, until today, "choice" has indeed been extended in the realm of marriage laws, but different kinds of religious choices still result in different status in law.

INDIA'S FIRST CIVIL MARRIAGE LAW, 1851 - 1852

If the British civil marriage law was part of a state effort to accommodate religious variety rather than ignore it, the law's extension to India in 1851 was marked by exponentially heightened awareness of the significance of religious differences. As in Britain, the claim of Nonconformists to conduct valid marriages without submitting to Anglican rites and ministry led to the legislation of India's first law of civil marriage. ${ }^{37}$ As in Britain, Anglican authorities vocally opposed this law, and as in Britain they were unsuccessful in preventing the law being passed. ${ }^{38}$ However, the outcome was quite different in India. There, because of the existence of other, Hindu and Muslim marriage laws recognized by the British government, the civil marriage law was restricted in application only to Christians. This formed the confused racial-religious core of the future "Christian personal law." A brief look at this process will indicate the manner in which the Indian "personal laws" formed an interconnected grid of competing jurisdictions, such that any proposed legislation in the field of domestic relationships was bound to encroach on the territory claimed by existing laws and their defenders.

Following more than a decade of petitions on the subject, in 1851 the British Parliament decided that there was an urgent need to extend the 1836 civil marriage law to India. Although Nonconformist ministers in India had submitted several petitions requesting such legislation (The Metropolitan, Bishop Daniel Wilson opposed it), the scales were tipped by the case of Maclean vs. Christall in the Supreme Court of Bombay in 1849. This was in essence a divorce case, although in form it consisted of the husband, Captain Maclean, seeking damages for "criminal conversation" from his wife's lover, a certain

\footnotetext{
35 Roderick Floude and Pat Thane "Debate: The Incidence of Civil Marriage in Victorian England and Wales," Past and Present 84 (Aug. 1979): 146-54, at 148-52.

36 David Pearl, "Muslim Marriages in English Law," English Law Journal 30, 1 (1972): 120-43, at 130 .

37 Act III of 1872 was not the first civil marriage law legislated by the British in India.

38 In particular see Daniel Wilson, Bishop of Calcutta and Metropolitan of India. See Second Report of the Commissioners Appointed to Enquire into the State and Operation of the Law of Marriage, Parliamentary Papers, House of Commons 1850 (1203), XX.363.
} 
Mr. Christall. ${ }^{39}$ The defendant's lawyer argued that by English law, specifically after Lord Hardwicke's statute of 1753, no marriage was valid unless a priest in holy orders officiated; in this case, the marriage was performed by a Congregationalist missionary, hence no marriage existed and no adultery could have taken place. He referred to an English case from 1842, Regina v. Millis, in which a husband argued a similar claim of non-existence of a first marriage when he married a second time. The judges refused to accept this precedent, correctly predicting that such a judgment would void most Christian marriages in India, where priests were few and far apart, and "bastardize" the children. The judges argued that the 1753 statute had never been introduced in India, ${ }^{40}$ but resort to judicial discretion on a matter of such broad significance revealed an urgent need for explicit legislation.

Since English statutes did not automatically apply to India (or to Scotland for that matter), Acts 14 and 15 Vic. Cap. XL of 1851, entitled an "An Act for Marriages in India," was enacted by the British Parliament and given effect by the Indian Act V of 1852, which provided for valid marriage before a registrar without religious ceremonies. Unlike the British law, it did not encompass the large majority of church marriages, whether Anglican, Roman Catholic, or Church of Scotland. ${ }^{41}$ The key point for this paper is that the Indian law began its career endowed with explicit confessional boundaries: its application was limited to Christians. This jurisdictional criterion was a revelation of the persistent failure of British imperial law to differentiate between "natives" and other "British subjects" in non-confessional terms; "Christian" was code for a category that could only be defined in negation: "non-native." ${ }^{22}$ But every taxonomic system has its own moment of force, hence the law did apply to some "natives": the "Native Christians," and thus formed the first of the statutes comprised in the future Christian personal law. ${ }^{43}$ This was not because British jurists thought Christianity made a person "British," or because they were unaware of the cultural difference between British and Indian Christians, but simply because they had no conceptual tools suitably "de-confessionalized" (secularized, if you like), to define persons without reference to religion, in the context of marriage. ${ }^{44}$ Since polygamy was at this time

\footnotetext{
39 Once adultery was proved, the wronged husband could seek a private bill for divorce in the British Parliament, the only method for a complete divorce in England before 1857. Ecclesiastical courts could only offer separation from "bed and board," divorce a mensa e thoro, although complete nullifications of marriage were available on grounds that the marriage did not ever exist.

40 Maclean v. Christall, Indian Decisions (Old Series), 17 vols. (Madras, 1912), v. 4, 69-83.

41 Clause 24, Act V of 1852. Later, Act V of 1865 superseded this law, providing for civil as well as church marriages, for Christians.

42 Throughout its proceedings, the Commission recognized the existence of a much larger pertinent issue, the legal regulation of Indian Christian marriages, but its final report declared such concerns beyond its competence.

43 For a history of the Indian Christian personal law, see Chatterjee, "Religious Change."

44 By Clauses 7 and 12, Act V of 1852.
} 
legally permitted to all other Indian men, a Christianity-derived law that compulsorily enjoined monogamy could obviously not apply to them. British jurists, understandably perhaps, refused to reflect on the academic possibility of a non-Christian Indian man choosing to bind himself legally to monogamy. Imposing this jurisdictional limitation on a law that was "after all" intended for British expatriates may appear commonsensical, but we will see how, through a similar process of turf-protecting by the personal laws and their advocates, a second civil marriage law intended potentially for all Indians was to be still further restricted in applicability.

The trajectory of the first civil marriage law of India alerts us, among other things, to the way in which a religious-legal tradition may be created. ${ }^{45}$ Scholars have commented on the distortion involved in transforming shari ' $a$ into the inelegantly named "Anglo-Muhammadan law," such that a generalized moralspiritual code and system of jurisprudence was limited in jurisdiction to a few "private" matters for a select group. ${ }^{46}$ But the transformation of the English civil marriage law into a "personal law" in India shows that very similar things could happen to British law in contexts that forced limitation of jurisdiction. With sharì' $a$ in India, scholars are unanimous that colonial state action produced this limitation, but what forced the British civil marriage law to limit itself to a tiny proportion of people residing in India?

\section{INDIA'S PERSONAL LAWS: RELIGIOUS LAW AS CIVIL/STATE LAW}

The easiest answer to that question is "religion," or the specific "Indian religions," namely Hinduism and Islam, since it was official British colonial policy not to interfere in Indian religions. A more specific reason is the unevenly adopted imperial policy of preserving and administering indigenous laws. This limited the extent to which British laws could be applied in India, producing very different effects for laws formally very similar to each other, such as the (British) Marriage Act of 1836, and the Act for Marriages in India, 1851. However, from the late eighteenth century, when this legal policy was adopted, the realm of indigenous laws lessened by constant attrition, until in the mid-nineteenth century it only implied the recognition of Hindu and Muslim laws of private relations, including laws regulating marriage and divorce, inheritance and succession, guardianship of minors, caste disputes, and religious endowments. ${ }^{47}$ The Indian "personal laws" encompassed more than the cluster that came to be called "family laws" under Western welfare regimes, and they were (and remain) a species of private law, dealing with

\footnotetext{
45 For the subsequent history of "Christian personal law" in India, see Chatterjee, "Religious Change."

${ }_{46}$ Among others, Ayesha Jalal, Self and Sovereignty: Individual and Community in South Asian Islam since 1850 (Lahore, 2001), 139-52.

47 It formally included contract until 1872, however.
} 
matters of interpersonal concern, but only matters of affect, which were believed not to interfere with the functioning of the state or the market. As such, the substantive law could vary with the particular religion that purported to be the source of a particular personal law, as well as the basis of the litigant's legal capacity. For example, if parties were Hindu, the disputes would be dealt with under Hindu law, ${ }^{48}$ provided the dispute involved marriage, divorce, or some other cause over which the personal laws had jurisdiction. Thus they were distinct from laws universally applicable within the territory of British India, which were the lex loci. ${ }^{49}$ Looked at from the other direction, the personal laws were inescapable when disputes fell within their jurisdiction, and since the application of a personal law depended on ascertaining the parties' religious affiliation, in such cases a lack of religious identity was simply not (and still is not) an option. ${ }^{50}$ So when in fact certain people, such as the Parsis or the Indian Christians, failed to fit the available categories, they revealed a jurisdictional vacuum that had to be quickly filled by the discovery of further personal laws.

The inception of this legal policy is commonly attributed to Warren Hastings' judicial plan of 1772, which was formulated to overhaul Bengal's administration and allow the East India Company to directly undertake its rights and duties as the Mughal diwan, and it is usually considered the moment of origin for the Indian personal laws. ${ }^{51}$ Clause XXIII of this plan, which ostensibly aimed to restore an ancient "Mogul constitution," declared, "That in all suits regarding inheritance, marriage and caste and other religious usages and institutions, the laws of the Koran with respect to Mahomedans and those of the

48 In cases where the parties were of different religions, the laws of the defendant applied. This provision was a fruitful source of judicial confusion, leading, among other things, to the codification of two additional personal laws, the Parsi and the (Indian) Christian.

49 A retired Calcutta Supreme Court judge explained this to the Royal Society of Arts in 1941. G. C. Rankin, "The Personal Law in British India," Journal of the Royal Society of Arts 89 (May 1941): 426-42. J.D.M. Derrett explored the persistent complexities this produced in determining the applicable law of, among other things, inheritable property, in "Private International Law and Personal Laws (based on Duggamma versus Ganeshayya), International Comparative Law Quarterly 14: 4 (1965): 1370-75.

50 As Marc Galanter explains, the definition of "religious identity" is in reality a description of civil status, not of religious belief or social behavior. "Hinduism, Secularism and the Judiciary," in Law and Society in Modern India (New Delhi, 1997), 237-58, at 241. Similarly, a person is assumed to be Muslim if his or her father is Muslim, unless he or she explicitly renounces the faith. Asaf A. A. Fyzee, Outlines of Muhammadan Law, 4th ed. (New Delhi, 1999), 60-64.

51 In 1765, the East India Company defeated an Indian coalition, which included the Mughal emperor. The defeated emperor granted the Company the diwani, or revenue-collection rights for the suba or Mughal province of Bengal. Until 1772, the Company tried to let the tremendous duties of collecting information and taxes, as well as the dispensation of civil justice, all of which was encompassed within diwani, be administered by the Mughal officials in situ. In 1772, following a severe famine and near-bankruptcy of the Company, it was decided to take over the functions directly. Among others, see P. J. Marshall, Bengal: The British Bridgehead (Cambridge, 1987), 70-92; Robert Travers, Ideology and Empire in Eighteenth-Century India: The British in Bengal (Cambridge, 2007), 118-23. 
Shaster with respect to Gentoos shall be invariably adhered to." The purported sources of these laws were religious traditions; initially sought by consulting Muslim and Hindu experts. ${ }^{52}$ Initial unquestioning reliance by the British judges on "native" experts for discovering what the Hindu and Muslim laws consisted of, quickly gave way to suspicion of such authorities. The earliest cadre of British Orientalists in India consisted most often of judges attempting to locate and translate the sources of Indian law unhampered by the obfuscations of suspect Indian experts, and supplementing their labors by building up a coherent body of case law that lent itself to consistent decisions in the manner of common law. ${ }^{53}$

Notwithstanding the official view of this policy as the preservation of indigenous laws, and by extension, of religion (since these two were supposed to be conflated in Indian tradition), scholars studying the Indian personal laws as a system have pointed out that, in fact, procedurally, substantively, and ideologically a new approach to law was being initiated. ${ }^{54}$ Inevitably, because of the conflation of law and religion, this was also a novel approach to the management of religious diversity. As Robert Travers has noted, whereas the Mughals had conceived of adjudication as a process distributed at various levels of society, the new system took the state to be the ultimate source of both rights and justice. ${ }^{55}$

The new state-centrism, combined with the effort to be "tolerant" of religious difference, meant that the new colonial government could not permit its jurisdiction to be fractured in the manner of the Mughal legal system. All that happened had to happen within a notionally unified system of law and courts, all deriving authority from the state. This legal approach created explicitly religious civil laws that were administered only by the state. The personal laws were from inception state laws: they did not represent the granting of legal autonomy to a limited religious sphere, but rather an active undertaking by the state to dispense religion as right.

This novel state project of administering multiple religious laws led to a new kind of "legal politics" in India. Contests that had once been played out in different social contexts were now redirected as claims on the state. Since neither

52 J.D.M. Derrett, "The Administration of Hindu Law by the British," Comparative Studies in Society and History 4, 1 (1961): 10-52, at 26.

53 Ibid., 32-34. Some important accounts of such translation projects, aimed at producing Hindu and Muslim law digests for the reference of British judges incapable of consulting the original sources are: J.D.M. Derrett, Religion, Law and the State in India, 2d ed. (Delhi, 1999), 225320; and Michael R. Anderson, "Islamic Law and the Colonial Encounter," in Peter Robb and David Arnold, eds., Institutions and Ideologies: A SOAS South Asia Reader (London, 1993), 165-85. Long after such digests became available, however, British judges sought to discover the law (not just clarify it) in difficult cases by posing questions to their Hindu or Muslim law officers. See, for example, the report of the case Gouree Pershaud Rai versus Musst Jymala, decided by the Sadr Diwani Adalat, Calcutta, in 1804. Indian Decisions (Old Series) (1912), vol. 4, 491-93. The posts of Hindu and Muslim law officers were officially abolished in 1864.

${ }_{54}$ Derrett, "Administration of Hindu Law," 34-37.

55 Travers, Ideology and Empire, 118-23. 
Hindu nor Muslim law was codified in the colonial period, ${ }^{56}$ the proposition that the state would administer these laws inevitably led to collective competition between Indian elites determined to instruct the state on what those laws were. Such competition was directly connected to concerns with maintaining or constructing particular patterns of interpersonal relationships, especially within families, from which derived a variety of material and non-material entitlements, such as shares in property or authority over subordinates. Any "resistance" to legislation in personal law matters was then a claim for alternative state action in favor of an alternative social vision, through legal declaration of or judicial enforcement of constantly discovered orthodoxies. Despite the rhetoric, there was actually little effort to exclude the state, especially in its judicial avatar, from an inner sphere of domesticity, religion, and the nation. ${ }^{57}$

\section{KESHUB CHANDRA SEN'S APPEAL FOR A LAW PRESERVING \\ THE MARRIAGE OF BRAHMOS, 1868}

It is now time to return to our principal protagonists, the Brahmos, and the reasons for Keshub's appeal for a law to validate their unorthodox marriages. Mody sees this as a request by Brahmos to be recognized as a "distinct "community' with legitimate rites of marriage," an appeal which was ignored by the colonial state, which instead introduced civil marriage, based on a more "individualistic conception of marriage based on the conjugal couple." ${ }^{\text {, }}$

But is this what happened? To begin with, the description of Brahmos as a distinct religious community sits uneasily with this law's divisive impact on the Samaj itself, which has long been recognized by scholars working on the Samaj. The divisions were over a number of key issues, and I would argue that the "self-excommunication" clause in the Special Marriage Act was the least important, although it was the best face-saving excuse for Brahmo conservatives. They had more material reasons for disliking a law which would in effect be a public test of their fidelity to the community's reformist ideals, since it set a minimum age of fourteen for the bride (with her guardian's consent) and eighteen for the groom, which would quite simply dash any hopes that Brahmo fathers might have entertained of marrying their daughters into orthodox Hindu families. In addition, their daughters' attractions in the broader Hindu marriage market would be significantly compromised by the

\footnotetext{
56 Digests were compiled, however, which in the common law tradition were sources of principles, and less reliable than either precedent or statute. In any case, British judges and jurists constantly complained that the early law digests were vague, self-contradictory, and silent on the topics that they heard disputes over.

57 In recent times, scholars have sought to qualify Partha Chatterjee's formulation by highlighting the continued colonial legal intervention, at the invitation of Indian elites, in the most intimate spheres of Indian life. Praveena Kodoth, "Courting Legitimacy or Delegitimizing Custom? Sexuality, Sambandham, and Marriage Reform in Late-Nineteenth-Century Malabar," Modern Asian Studies 35, 2 (2001): 349-84, at 355-56.

58 Mody, "Love and the Law," 229.
} 
law requiring the husband to commit himself to monogamy for life. Certainly, the Young Turks within the Samaj were eager to use this tool to discipline those that they saw as hypocritically lax about putting their religious and social principles into practice, and the law was to be their acid test of membership in what they increasingly saw as a distinct group, the community of Brahmos. ${ }^{59}$ The declaration required of parties that they did not belong to any major recognized religions of India, including Hinduism, was rather superfluous, once Brahmos practically made their daughters unmarriageable by refusing to marry them under fourteen and threatening their potential son-in-laws with criminal action should they ever take another wife. Unmarriageable daughters of upper caste fathers effected their excommunication much more effectively than any declaration of self-excommunication could. This was of course a necessary sacrifice, or not even a sacrifice, for those keen on developing a coherent sense of Brahmo community, among other things because it discouraged doctrinally suspect intermarriage between idolatrous Hindus and monotheistic Brahmos.

The irony was that Keshub, the leader of the "progressives" at the time of seeking legislation, was himself put to the test and found wanting when, in 1878 , he permitted his thirteen-year-old daughter Suniti to marry the heir to the Kuchbehar throne, in a wedding replete with traditional Hindu ceremonial. ${ }^{60}$ This widely publicized and debated marriage led to a further split among the progressives in the numerically tiny Brahmo Samaj. But why did Keshub walk into such a trap?

To understand the historical reasons for the creation of India's second civil marriage law, the Special Marriage Act of 1872, it is essential to understand the principal concerns that motivated Keshub Chandra Sen's original petition to the government in 1868. All too often scholars have concentrated on features of the law which in retrospect appeared "reformist" and "progressive," such as a minimum age of marriage, the validity of inter-caste marriage, and monogamy, and have thereby assumed that the law was demanded and secured by the "reformist" section of the Brahmos. ${ }^{61}$ It was, but Keshub was neither out to enforce reform on the Samaj nor interested in securing recognition for Brahmos as a distinct religious community. Quite the reverse; he wanted to secure the validity of unorthodox Brahmo marriages that arose out of their existing reformist practices,

59 For this reason, Sibnath Sastri, an important "radical" Brahmo, engendered the proposition that with the passing of the Special Marriage Act, the break between Hindus and Brahmos became complete. Amiya Sen, Hindu Revivalism in Bengal 1872-1905: Some Essays in Intepretation (Delhi, 1993), 135. As Sen points out, Sastri's wishful thinking was transmuted into a fact through its frequent repetition by future scholars.

60 Meredith Borthwick, Keshub Chandra Sen: A Search for Cultural Synthesis (Calcutta, 1977), 174-201; David Kopf, The Brahmo Samaj and the Shaping of the Modern Indian Mind (Princeton, 1979), 138-41.

61 Kopf, Brahmo Samaj, 103-5. 
ensure the legitimacy of children born of such marriages, and most crucially, protect the inheritance rights of the family so created. His concerns made perfect sense in the context of the constant conflict Brahmos faced with conservative Hindus, who were often members of these same families.

Anybody acquainted with the British legal approach to marriage would be concerned regarding the validity of Brahmo marriages in the eyes of law. As described above, since the mid-eighteenth century all marriages in Britain, to be valid, had to conform to specific statutory provisions that defined the range of rites that could be practiced. Jewish and Quaker marriages by their own ceremonies were valid because of express legal sanction given to them. For colonies, the validity of non-Christian marriages also had to be explicitly preserved by exemption. ${ }^{62}$

That Keshub was well aware of the risks associated with unorthodox marriages is revealed in his first missive to the advocate-general of Calcutta, and the response revealed the particular legal problem the Brahmo Samaj was faced with:

Q. Whether, in the absence of a special enactment, the general spirit of English law is favourable to marriages contracted between individuals of a new religious community, under purely moral and religious necessities and upon principles and after a ritual not sanctioned by any existing legally recognized communities, or will it hold such marriages to be illegal at once?

A. I hardly know how to answer the first question. Putting out of question marriages solemnized in foreign countries, the only marriages which the general English law formerly recognized, other than marriages solemnized according to forms of that law, were those between Jews and Quakers. The recognition of marriages between Quakers was of very gradual introduction, and can hardly be said to have been established until such marriages were referred to in, and exempted from, the English Marriage Act of 1753. Under the more recent Registration Acts, in England, persons belonging to any particular religious body may have their marriages solemnized according to the form adopted by such religious body, but those marriages derive their legal validity exclusively from the presence of the Registrar. In the absence of special enactment, a marriage between two members of a new religious community, such as the Brahma-samaja, not celebrated in accordance with the provision of any of the Marriage Acts in force in India nor with those required by Hindu law, would, I apprehend, be invalid.

Q. How far are such marriage-contracts binding on the parties who marry? If the wife be deserted by her husband without any just cause, or denied the necessaries of life, will the law under the present circumstances give her any protection?

A. It follows that, in the present state of the law, such marriages as last adverted to are not binding on the parties, and that the (so-called) wife would have no legal redress if deserted by her husband, nor would the offspring of such unions be legitimate, or

62 The absence of such a law preserving Hindu and Muslim marriages in South Africa, for example, led to the threat of their invalidation when the Cape Supreme Court ruled in 1913 that marriages conducted under the rules of a religion that permitted polygamy were invalid. Following Gandhi's satyagraha, Hindu, Muslim, and Parsi marriages were given express recognition by the Indian Relief Act, 1914. R. A. Huttenback, "Indians in South Africa, 1860-1914: The British Imperial Philosophy on Trial,” English Historical Review 81 (Apr. 1966): 273-91. 
have any rights of succession, though it would of course be perfectly competent for the parents to provide for such children by will.

Keshub of course, could not anticipate this damning answer, but wanted to check: "If such marriage-contracts be binding for all legal purposes on the parties marrying, will their children be entitled to their property after their demise as their legitimate children, in case they expressly make such provision in their will? Will such children be entitled to their property in the absence of a will?" The advocate-general answered:

Any provision made by will by a member of the Brahma-Samaja in favour of his children would be paramount to the claims of any Hindu relatives, and this would extend, so far as Bengal is concerned, to the father's share in ancestral, as well as to this selfacquired property. In the provinces other than Bengal, where the testamentary power is more limited, and also in the absence of a will, the children would not be entitled to the succession. But even where the Mitakshara law prevails, the father may leave by will his self-acquired property to his children by a marriage according to the forms adopted by the Brahma-samaja. It would be a prudent precaution in all cases for the testator to name the children whom he intends to make his devisees, and not merely refer to them as his children or sons or daughters. ${ }^{63}$

In other words, the children could be protected to a certain extent by a father of independent means, and by a very carefully worded will. The situation did not appear reassuring at all, and the advocate general himself recommended that they acquire an "authoritative legal decision" on the issue.

Hence Keshub appealed to the Viceroy's Council for the validation of marriages by Brahmo rites, a kind of appeal that British legislators were very familiar with, given numerous nineteenth-century legislations to validate marriages by different Christian rites. Henry Maine explained to the Viceroy's Council his reasons for a more general, but not universal law:

It has been unavoidable to make the measure more general than was at first intended. I certainly hold it to be good policy in India, considering the unknown depths of native feeling on the subject, to confine relief in matters connected with religion as much as possible to the class that seeks it and establishes a case for it.... I would have gladly limited the operation of this Bill to the Brahmo sect. But after much conversation with Baboo Keshub Chunder Sen, I find that the sect has passed through many phases of religious feeling. The process by which it is recruited, the abandonment by young educated Natives of Hindooism and of Hindoo rites is unquestionably on the increase, but reluctance to enroll themselves in any one sect, or to profess any definite creed, is increasing also. In the column of the register of the Calcutta University in which the "religion" of the undergraduates is recoded, may be seen every sort of novel creed —“"Theist," "Vedaist," "Pantheist," and "Spiritualist" are among the commonest, and it is to be recollected that the young men who so describe themselves have about reached the age at which Natives marry. If then we confine the measure to "Brahmos," we might

63 "Papers Relating to the Bill to Legalize Marriages between Certain Natives of India not Professing the Christian Religion," No. 12, India Bills Objects and Reasons, 1872, L/PJ/5/15, Asia Pacific and Africa Collections, British Library. 
have applications for a fresh measure soon declaring that they could not conscientiously subscribe to the Brahmo creed.

As Maine had correctly diagnosed, being "Brahmo" was only one in a spectrum of religious-social experimentation among the volatile and vocal class from which the appeal arose. He therefore proposed a native marriage act that would provide for civil marriage (before a registrar) for those who were not Christians (since civil marriage for Christians had already been provided for, and had distinct conditions for eligibility), and who did not wish to celebrate their marriage by Hindu, Muslim, Buddhist, Parsi, or Jewish rites. ${ }^{64}$ Once again, race and religion overlapped unevenly in the creation of an Indian civil marriage law, mirroring the racial and confessional limitations of the civil marriage law of 1852 that was meant only for Christians.

Within the problematically defined racial-confessional jurisdiction of the law, Maine revealed no intention to facilitate the progress of Indian society from status to contract, expressing much greater concern that religious dissent (i.e., conscientious objections to using a certain marriage rite) might become a route for evading parental and social control. Keshub had proposed that the bride and groom had to be at least fourteen and eighteen years of age, respectively, but Maine said: "The power of civil marriage might be abused by inducing the daughters of orthodox Hindoos to marry against their parents' wishes," and so he thought it necessary to add the requirement of parental consent for brides up to the age of eighteen. In the imperial context, all aspects of liberalism were susceptible to radical inversion. Maine intended to offer toleration for religious dissent, not license for social revolution. Even in this limited aim he made, as subsequent events showed, an inadequate assessment of the legal devices required. Keshub, making a shrewder guess, wanted a legislative declaration that descendants of persons marrying under the Act should inherit according to the law of inheritance applicable to the last ancestor who professed a recognized native religion. That is, if a Hindu became Brahmo, and married under the proposed law, his children could claim their entire inheritance, both ancestral and personal, under Hindu law. Keshub, therefore, had no intention of forcing an exit from the circle of kinship and property relations for those Brahmos who married under the new law. That is, he had no particular interest in marking the distinct "identity" of Brahmos in law. Neither did Maine, but he felt that such a specific clause regarding inheritance rights was both rigid and unnecessary. In his view:

All which the Brahmos require is given by the existing law as laid down by the Privy Council in a most important case Abraham v. Abraham (Moore's Indian Appeals, p. 195). It was there decided that a Native abandoning Hindooism or Mahometanism as a religion may at pleasure continue to live under Hindoo or Mahometan civil law, or may exchange it for any other recognized set of usages. The provision, therefore,

${ }^{64}$ Minute by Henry Maine... (see n. 14 above). 
requested by the Brahmos would in reality abridge their liberty. A Brahmo may wish to adopt Christianity, and with it (as with the case with the parties in Abraham $v$. Abraham) English law. There seems no reason for preventing his doing so. ${ }^{65}$

As it turned out, Maine was wrong; he had failed to appreciate the direction of the personal laws as a system, which would make such a civil (as non-religious) arena of marital and property relations elusive, if not impossible.

THE SECOND STAGE: A BRAHMO MARRIAGE LAW

The huge volume of protests against this draft law can be traced to two sources: those who thought that the law, by its permissiveness, included their social or religious group and by doing so, undermined established social and religious authority, and the Brahmos themselves. These were dealt with, not by Maine, but by Fitzjames Stephen, Maine's nominated successor to the office of the law member of the Viceroy's Council. Stephen was a Benthamite devoted to codification of law, creating in his Indian career the Indian Evidence Act, Contract Act, and a revised code of criminal procedure. ${ }^{66}$ Uniformity rather than permissiveness was his forte: encountering the protests described above, Stephen considered a law that was explicitly restricted to Brahmos. However, this measure led to panicked protests from all those members of the Brahmo Samaj, who did not wish their professed social progressivism to be legally prescribed for them.

Permissiveness became a problematic category because it was being precisely defined against what it was not, among other things that it was not Hindu. It appeared that if a certain set of marriage practices, and by derivation, those that followed those practices, were classified as permissive, hence nonHindu, one then was subjected to novel conditions for the privilege of enjoying the right to such marriages. The problem with such conflation was forcefully represented by the protest of the Coorgs, whose social customs would later achieve international fame among sociologists. ${ }^{67}$ In 1869 , in response to a circular to all Provincial governments regarding the viability of the legislation, the

\footnotetext{
65 This, then, should be a correction to a study of Abraham v. Abraham that has suggested the case represented British efforts to forcibly reinstate converts to Christianity within the Hindu community they had exited. As Chandra Mallampalli has rightly pointed out, there is no reason to assume that such converts wished to deprive themselves of inheritance under Hindu law in the first place. Gauri Vishwanathan, Outside the Fold: Conversion, Modernity and Belief (Princeton, 1998), 75-117; Chandra Mallampalli, Christians and Public Life in Colonial South India 18631937: Contending with Marginality (London, 2004), 21-80, especially with regard to inheritance laws, 38-58. This is equally true of Brahmos, and that should lead us to query the grouping of a large range of religious behavior as "conversion," or a complete self-removal from one system of belief, practice, and sociality to another.

${ }^{66}$ K.J.M. Smith, "Stephen, Sir James Fitzjames, First Baronet (1829-1894)," Oxford Dictionary of National Biography (Oxford, 2004); online ed., May 2006, http://www.oxforddnb.com/view/ article/26375, accessed 23 May 2010.

${ }^{67}$ M. N. Srinivas, Religion and Society among the Coorgs of South India (New Delhi, 2003 [1952]).
} 
chief commissioner of Coorg reported that leading men among the Coorgs had no objection to the validation of Brahmo marriages, but did not themselves wish to come under the provisions of the proposed law. Perhaps with some nudging from Superintendent of Coorg R. A. Cole, who was a bit of an amateur anthropologist, they said that they were not Hindus, and did not follow the ritual of Hindu religion. But they asked that this should not lead to the new law being imposed on them, since if it were, it would effectively invalidate marriages which were customary among them, because of the prohibited degrees of kin provided for. Coorg men and women, like many other South Indians, customarily married their cross-cousins, ${ }^{68}$ who would be considered too closely related under the new law. ${ }^{69}$ Besides, inclusion in the new law appeared to validate inter-caste marriage, which was completely unacceptable to Coorgs. The judicial commissioner of Coorg also pointed out to the chief commissioner a potential grievance: the Coorgs by coming under this law would be forced to be monogamous. ${ }^{70}$ Why did the Coorgs have to give up so much to enjoy the right to their customary marriages?

A similar point about over-inclusion was made by the Maharaja of Benares, a leader of Hindu orthodoxy in north India, but from a very different perspective. ${ }^{71} \mathrm{He}$ complained that altogether too much importance had been given to the difficulties of Brahmos. In his part of the country, Chamars and outcastes (and obviously he felt that Brahmos were a similar category) did not marry by Hindu ritual, but no one had ever questioned the validity of their marriages. Marriages among Brahmos were a matter of similar indifference to orthodox Hindus, but it was unacceptable that, to accommodate them, a law implicitly recognizing inter-caste marriages should be imposed on Hindus in general. In any case, because of Act XX of 1850, converts out of Hinduism, including "Brahmists," retained their share of ancestral property, and could even pass it on to their widows, in contravention of Hindu laws of inheritance. He did not wish such permission to be extended to all outcastes. ${ }^{72}$

Both of these objections had an implicit third point, regarding the issue of penalties attached to social deviance. The Parsi petition from Bombay made this clear by urging that a person who married under the law, declaring that he did not wish to follow Zoroastrian rites of marriages, should be placed outside the Parsi community for all purposes, that is, for inheritance as

${ }^{68}$ For men, these were their father's sister's daughters, and mother's brother's daughters; for women, their father's sister's sons, and mother's brother's sons.

69 The schedule of prohibited relationships, provided by Keshub, represented the cultural specificity of upper-caste Hindu Bengali marriage practices.

70 Chief Commissioner Coorg to Sect. to the Council of the Governor General of India, 12 May 1869 , in "Papers Relating to the Bill to Legalize Marriages...."

71 Vasudha Dalmia, The Nationalization of Hindu Traditions: Bharatendu Harischandra and Nineteenth-Century Banaras (Delhi, 1997), 64-82.

72 Memorandum of the Deputy Superintendent of the family domains of the Maharaja of Benares, 24 Dec. 1869, in "Papers Relating to the Bill to Legalize Marriages...," No. 9. 
well. ${ }^{73}$ The Parsi approach was not to question the validity of the unorthodox marriage itself, but to exclude those who undertook it from legal relations enabling inheritance, which was in line with the particular history by which an increasingly restricted definition of "Parsi-ness," premised on a conflation of race and religion, was developed. ${ }^{74}$

Faced with these objections, Stephen referred the bill to a select committee which he chaired, which decided in early 1871 that the law should be restricted only to those Brahmos who were prepared to declare their distinctiveness with the prescribed declaration: "I am a member of the Brahma Samaja."75 Note here that the legal definition of Brahmos as a "community" was not a demand made by any Brahmo, but a legal device proposed by embattled British legislators, who thought that a "Brahma Marriage Act" would smooth ruffled feathers. They were wrong, because this time there was a rush of petitions from various shades of Brahmos (and no one could be blamed for being unacquainted with all the varieties within this numerically tiny but highly volatile religious spectrum). From Simla, a petition of Brahmos bearing 2050 signatures expressed alarm at being subjected to a Brahma Marriage Act, for which they saw no need, and which would severe them from the general body of Hindus, of which they were an integral part. They resented the assumption that the present form of marriage among Brahmos was not valid and required legislative correction. In their view, their marriage ceremonies represented the purest form of Hinduism, and in any case, new sects with novel rituals had often arisen within Hinduism, and their legality had never been questioned. As for a minimum age of marriage for girls, and monogamy, all high-minded Hindus recommended such things, including the Sanatana Dharma Rakhini Sabha. However, it was argued, there was no need for a law to suppress practices that had to die down through evolution. ${ }^{76}$

The Brahmo petition was the exact obverse of that of the Coorgs: both sets of petitioners resented being subjected to a law of marriage that restricted the existing rights of male members of the social group, as a price for privileges they already possessed. Coorg marriages were customary, and the AdiBrahmos (Debendranath's more conservative, "Hindu-Brahmo" group) did not feel that their marriages were unorthodox. All felt that provisions for male monogamy and prohibition of underage marriage an imposition: although

\footnotetext{
73 Memorandum by Honorable Mr. M. J. Shaw Stewart, dated 27 Feb. 1869, forwarding petitions of Mr. Framjee Nesserwanjee Patel and Mr. Venayekrow Juganathjee Sunkersett, in "Papers Relating to the Bill to Legalize Marriages...," No. 1.

74 See Mitra June Sharafi, "Bella's Case: Parsi Identity and the Law in Colonial Rangoon, Bombay and London, 1887-1925," Ph.D. thesis, University of Princeton, 2006.

75 "A Bill to Legalize Marriages between Members of the Brahmo Samaja (as Amended by the Select Committee)," 27 Mar. 1871, in India Bills, Objects and Reasons, 1872, L/PJ/5/15, Asia Pacific and Africa Collections, British Library.

${ }^{76}$ To the Viceroy, from members of the Brahma Samaja, Simla, in "Papers Relating to the Bill to Legalize Marriages...," No. 14.
} 
all Brahmos officially recommended such measures, it was quite another thing to be have them made compulsory by law. One might argue that had this law been passed Keshub would have had even less moral space to obfuscate about his daughter's marriage.

THE FINAL STAGE: A LAW FOR THOSE WhO BELONGED NOWHERE 7

Fitzjames Stephen now chaired a second Select Committee to reconcile the objection of Brahmos that they were not unlike Hindus, with objections from everybody else that they were not like the Brahmos. In any case, almost everybody was concerned to avert the risk of social permissiveness being unleashed, for Brahmos this translating as social progressiveness being imposed. Hence the final version of the law, which as Act III of 1872 received the assent of the governor general on 22 March 1872, applied to parties who would declare that they did not profess the Christian, Jewish, Hindu, Muhammadan, Parsi, Buddhist, Sikh, or Jaina religions, and subjected them to the contentious age, kinship, and monogamy restrictions. Not all were satisfied: a conservative Hindu, Kali Prasanna Banarji, objected that "not Hindu" was an overly capacious category, and that it might be used by Hindus who were morally lax, or had violated caste and ritual rules, to avoid costly expiatory rituals. All they needed to say was that they were "not Hindu," and of course marry a person willing to say the same, and they would be beyond the regulatory power of Hindu society. In his opinion, if "Brahmo" had proved too broad a category, the law could have been further restricted, for example to "Progressive Brahmos" or "Keshubites." "78 Having seen the effects of the proposed Brahma Marriage Act, Stephen refused to be drawn in once again into defining such a volatile and argumentative set of Indians, and he chose instead to leave the law's jurisdiction open to choice.

\section{WHO WERE THE BRAHMOS?}

The personal laws were (and still are) based on a theory of social organization, which assumed the objective existence of finite and mutually exclusive social groups defined by religion, each potentially possessing a personal law, subject to it becoming articulately self-aware. Many scholars have observed in the context of larger and arguably less labile communities that social reality was distinctly more complex than the law would have it. I would add that people nevertheless engaged actively with the flattening legal categories, not only to

\footnotetext{
${ }^{77}$ I find Mody's use of the term "not-community" to describe "love-marriage" couples interesting, except that it appears to assume the objective existence of "communities." I take the view that "community" is a species of political argument, as well a manipulative category of legal governance.

${ }_{78}$ Opinion of Babu Kali Prasanna Banarji, 1 Feb. 1872, in "Papers Relating to the Bill to Legalize Marriages...," No. 18. Two days later, Kali Prasanna also warned that such marriages would be considered invalid by society.
} 
resist them, but also in many cases to manipulate them for their own purposes. The conflicts described among those that called themselves Brahmos represent the tip of the iceberg; constant disputes over the membership of personal law communities is endemic to the system, which offers different legal privileges dependent on one's personal law status. The attractions of any particular privilege depend on a person's or group's subject position.

Who the Brahmos were, therefore, depended on who was speaking, and for what purpose. The range of legal conceptions of the category "Brahmo" that we can perceive during the debates preceding the enactment of Act III of 1872 derived from the larger debates about religious identity in the volatile world of religious, social, and personal experimentation that was nineteenth-century upper caste Hindu society, the nascent bhadralok. David Kopf's seminal work on the Brahmo Samaj identified two principal lines of self-identification among the Brahmos: those who tended towards chauvinistic Hindu nationalism and those inspired by a liberal, reformist humanism. It appears to me that "reformism" is a category that needs further attention, especially with reference to the rise of the sectarian reformists, who moved from an interest in transforming wider society to one in converting individuals. But then, what is it that makes a religious community just that: is it theological and ceremonial creativity, such as the Tagores were renowned for, or a social burning of bridges, which, as Christian missionaries often noted, could equally be a sign of atheism and social rebellion? Rabindranath Tagore's novel Gora, which Kopf has also utilized, ${ }^{79}$ reveals a much more complex picture of the variety of ways in which a person could be a Brahmo, for all or part of their life, each position involving a specific relationship with that overwhelmingly large and amorphous entity that is Hindu society. ${ }^{80}$ In this novel, a marriage between a "Brahmo" woman and a "Hindu" man is alternatively defined as betrayal of Brahmos, betrayal of Hinduism, and betrayal of the nation (defined by Hinduism), and Tagore's favored position, as a valid union affirming the uplifting, vague, spiritual-ethical domain that is Hindu/Indian, but humane and liberal enough to accommodate some doctrinal and social experimentation. Nowhere is it simply a marriage between two individuals, although it is their mutual attraction that produces the drama.

The text offers more than this rather pious resolution. It is a vivid picture of a society that Rabindranath, as son of Debendranath Tagore, was well acquainted with. The Tagore family itself included several shades of social practice and religiosity, including that of Debendranath's eldest son Satyendranath, who followed the "reformist" wing of the Brahmo Samaj, ${ }^{81}$ and non-Brahmo Hindus

79 Kopf, Brahmo Samaj, ch. 10 on Tagore.

80 Rabindranath Tagore, Gora, in Rabindra-rachanabali (Calcutta, 1964), vol. 6, 109-574. I am grateful to Professor Tanika Sarkar for alerting me to the crucial relevance of this text to a discussion of civil marriage laws in India.

81 Kopf, Brahmo Samaj, 132. 
who pursued Hindu "idolatry" with gusto. Sen's legal concerns, then, arose from this complex social context, where "Hindu" "Brahmo," and "Adi Brahmo" were positions along a spectrum of socio-religious debate, and not necessarily rigidly separable. The law therefore had to deal not only with the question of what to do with Brahmos, but who the Brahmos were, and the three distinct stages that the law passed through represented three different ways of legally accommodating an active religious movement in the context of a legal conception that took religious identities to be stable and isolable.

\section{CONCLUSION}

It is now time to draw some conclusions from the historical narrative outlined above. What should we make of this process of demanding, making, and using the law? I have argued against the idea that civil marriage, especially the Indian civil marriage law, was the product of a European ideology of complete religious individualism, which in turn was the product of a process called secularization. The secularization of Europe is a doubtful proposition, if by secularization one means the irrelevance of religious status to the process of governance. What is outstanding about British marriage laws at the beginning of the nineteenth century is hardly the irrelevance of religion, but the enforcement of very different civil implications for different religious choices. As the century wore on, these implications became less divergent: Catholics could be elected to Parliament and admitted to university, and Nonconformists could marry in their own chapels, at first under the supervision of a state-appointed registrar and later without it. But the political arguments used to wear down these "discriminatory" legal provisions, to use a somewhat anachronistic term, were themselves discriminatory. Nonconformists appealed for the recognition of their religious ceremonies as equivalent to the Church of England's rites, and in doing so, asked for their piece of the state, so to say.

The religious politics of British-ruled India were not in essence very different. But the interest in individuated religious liberty was much more muted in the colonial context, where the state was not just willing but eager to demonstrate its liberalism, or rather liberality, by recognizing that at their core Indians were bound to be different from the British and from each other, and thus that what was required were (limited) domains of law sourced from various religions. The effect of the system of personal laws was to transmute the language of religious tolerance in colonial India to mean the tolerance of collective religious differences, hence "rights" being demanded on behalf of and accorded to entities called religious communities. Even when people disagreed about the boundaries of such communities, or the orthodoxy of any one of them, hardly anyone disputed that collective identities were relevant to law, or ought to be.

On the other hand, the personal laws, especially their regulation of conjugality and property, provided potent disciplining tools, both for constructing and 
policing the boundaries of religious communities. To deviate from orthodoxy or to be accused of it could mean not just risking the displeasure of kith and kin, but also potentially losing the right to enter into a valid marriage or entitlements to shares in coparcenary property, just as Keshub feared that Brahmos might. His solution and that of Maine, which was basically a pre-emptive one of preventing ostracism and disinheritance for doctrinal and social deviation, proved impossible given that conservative Hindus could defend the right to discipline members of the community defined by Hindu personal law, claiming this right as a religious one.

There could have been one other outcome: a Brahmo personal law, somewhat like the Christian personal law, eventually developing its own orthodoxies and replicating arguments about religious freedom to discipline deviants. But the Brahmos, unlike Christians, were too vocal, too organized, and too similar to other upper caste Hindus to submit to a set of laws that would make their progressive principles inescapable. And here we see the difference between Nonconformists in Britain and Brahmos in India: while a Nonconformist man could marry in England or Wales before a registrar or in a chapel without fundamentally altering the nature of his domestic and social relations, no man marrying under the proposed "Brahma Marriage Act" could ignore that he was burdened with legal obligations that most other men were not, such as to limit conjugality to one woman for the rest of his life. Not that all Brahmo men, or even all Hindu men were rabid polygamists, but one has to take into account the psychological repulsion of being permanently deprived of a privilege that clearly marked the distinction and hierarchy between men and women in nineteenth-century India. The solution, then, was the Special Marriage Act, whose jurisdiction was entirely permissive. For the same reasons that Brahmos were unwilling to submit to the Brahma Marriage Act, few Indians wished to avail of this apparently emancipatory permission.

Since the days of Michael Madhusudan Dutt, there had of course been Indian men who expressed dissatisfaction with traditional marriages, and sought in their wives intelligent and supportive partners, even romantic love. ${ }^{82}$ These usually upwardly mobile professional and mercantile advocates of the nuclear family were however less interested in signing a bond to monogamy ${ }^{83}$ than in extracting themselves from the web of obligations to other male agnates and corporate entities that defined the traditional Indian family and society, although in legally specific ways for Muslims,

\footnotetext{
${ }^{82}$ For Madhusudan's desperate resistance to a marriage arranged for him, see Ghulam Murshid, Ashar cholone bhuli (Calcutta, 1995), 42-44, 53-58.

${ }^{83}$ In 1836, when Ardasir Wadia violated Parsi customs of monogamy by abandoning his first wife and marrying another woman whom he presumably found more companionable, the younger generation of Parsis prevented the Parsi panchayat from taking action against him. Susan Stiles Maneck, The Death of Ahriman: Culture, Identity and Theological Change among the Parsis of India (Bombay, 1997), 173-75.
} 
Hindus, and Parsis. ${ }^{84}$ There was nothing in the Special Marriage Act that promised such an escape route, at least not until the amendment of 1923, when the removal of the "self-excommunication" clause allowed people using it to continue to be Hindu, Muslim, or whatever the case might be, with the proviso that the Indian Succession Act of 1865 would apply to their property. The Indian Succession Act was legislated in 1865 as part of the unfinished Indian Civil Code; quite like the "Indian Marriage Act" of 1852, it limited itself to Christians (and its testamentary sections to Parsis) by giving exceptions to Hindus, Muslims, and Parsis. Modeled on British inheritance laws, this law gave primacy to the nuclear family-property devolved to the widow and children, rather than male agnates - but only posthumously. The would-be romantic husband found in that provision very little to entice him.

${ }^{84}$ On the efforts of such men to separate their personal earning from partible ancestral estates, see David Washbrook, "Law, State and Agrarian Society in Colonial India," Modern Asian Studies 15, 3 (1981): 649-721, esp. 674, 700; Mytheli Sreenivas, "Conjugality and Capital: Gender, Families and Property under Colonial Law in India," Journal of Asian Studies 63, 4 (2004): 937-60. 